\title{
Is the hydrological function of Lake Wigry changing?
}

\author{
Elżbieta Bajkiewicz-Grabowska
}

Department of Limnology, University of Gdańsk, Bażyńskiego 4, 80-952 Gdańsk, Poland, e-mail: bajka37@wp.pl

\begin{abstract}
The paper considers whether in recent years there have been changes in the structure of the water circulation in Lake Wigry, the main water body of the Wigry National Park. The volume and trends in the streams of water exchange in the lake have been assessed. They show that in recent years the horizontal water exchange is being reduced as the inflow to the lake is growing, mainly due to its main tributary, the Czarna Hańcza, while the outflow from the lake is decreasing. The paper examines whether these changes are reflected in the structure of the lake water circulation, which has been assessed on the basis of the lake water balance.
\end{abstract}

Keywords: lake water balance, horizontal water exchange in a lake, underground water exchange in a lake, Lake Wigry.

\section{Introduction}

Lake Wigry is the tenth lake in Poland in terms of the volume (2163.3 ha) and fifth in terms of the depth $(73 \mathrm{~m})$. It lies en route of the Czarna Hańcza River (tributary of the Neman), within the Wigry National Park and - alongside other lakes - it contributes to the unique natural value of the park. Lake Wigry is the water receiver from an area of $487.24 \mathrm{~km}^{2}$ (IMGW 2005), which is the total catchment area of the lake. The direct water supply area of the lake (direct catchment) covers $74.76 \mathrm{~km}^{2}$.

Wigry is a deep lake of varying morphology and morphometry (incl. Bajkiewicz-Grabowska 2009). The water level of Lake Wigry has been recorded with breaks since $1926^{1}$. In the period from 1949 to 2012 the average level of Lake Wigry was balanced and referred to the ordinate of $131.92 \mathrm{~m}$ above the mean sea level in Kronstad, which corresponds to the annual mean water stage of $107 \mathrm{~cm}$ (Fig. 1). The mean amplitude of the annual water levels in this period was $45 \mathrm{~cm}$ (the average high water level was $130 \mathrm{~cm}$, the average low water level was $85 \mathrm{~cm}$ ), while the extreme amplitude was 85

\footnotetext{
${ }^{1}$ Initially, measurements were conducted at the gauging station in the village of Płociczno, in the years 1928-1933 and 1947-1970 at the station in Stary Folwark, and since 1971 at the station in Wigry (Ploso Wigierskie).
}

$\mathrm{cm}$ (highest water level $161 \mathrm{~cm}$, lowest water level 76 $\mathrm{cm})$. The average annual water level during this period showed a statistically insignificant downward trend. Similar results were obtained by Dąbrowski (2002), and Dąbrowski and Węglarczyk (2005).

The previous studies on the water circulation in Lake Wigry (Bajkiewicz-Grabowska 1999, 2002, 2009) show that it belongs to those reservoirs in which the water level is determined by two types of water exchange: horizontal water exchange (the difference between the river inflow and outflow) and the underground water exchange (the resultant underground supply). In the years 1971-1990 the lake basin received annually $115.637 \mathrm{hm}^{3}$ of water on average, while the amount flowing out via the river Czarna Hańcza was $124.457 \mathrm{hm}^{3}$ (Bajkiewicz-Grabowska 2002). The ratio of the river inflow to the outflow in this period was 0.93. In the period from 1971 to 1990 the annual underground water exchange in the lake (the difference between the underground supply and drainage, i.e. the resultant underground supply) constituted on average $57 \%$ of the total volume of the water circulating in the lake, which was $5.067 \mathrm{hm}^{3}$. The volume and character of this type of water exchange depended on the underground water supply, which means that - in the annual scale - Wigry is a lake which drains aquifers. 


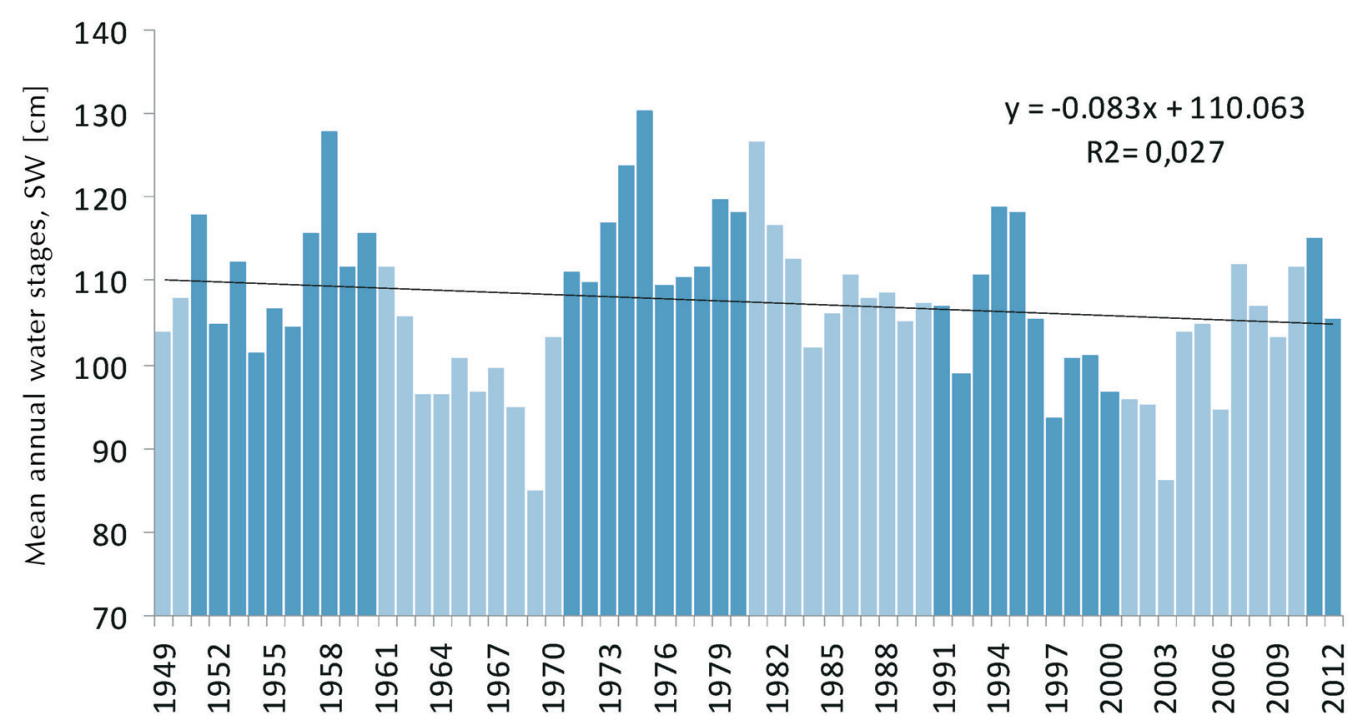

Fig. 1. Mean annual water levels of Lake Wigry: 1949-2012 (water gauge Wigry, data by IMGW)

\section{Results}

Water exchange in Lake Wigry in the years 1951-2012

The existing research results indicate that the structure of the water circulation in Lake Wigry is shaped by the horizontal water exchange, i.e. the difference between the river inflow and outflow from the lake. The volume and dynamics of the inflow to Lake Wigry is primarily determined by the Czarna Hańcza River (Fig. 2), which supplies into the lake from 37 to $87 \%$ of the total inflow (an average of $60 \%$ ). The second tributary is the hydrometrically uncontrolled Piertanka, feeding into the lake from 10 to $47 \%$ of the total supply (an average of approx. 31\%).

The analysis of the variability of the average annual discharge of the Czarna Hańcza, based on the data from the years 1951-2012 gathered above its confluence with Lake Wigry (IMGW gauging station at Stary Bród ${ }^{2}$ ) and below the outflow from the lake (IMGW gauging station at Czerwony Folwark), indicates that the average annual discharge of this river was as follows:

$\Rightarrow$ upstream of its opening to Lake Wigry - from 1.26 $\mathrm{m}^{3} \mathrm{~s}^{-1}$ (2006) to $4.40 \mathrm{~m}^{3} \mathrm{~s}^{-1}$ (1990), with an average annual discharge of $2.11 \mathrm{~m}^{3} \mathrm{~s}^{-1}$; at this gauging station a year-to-year increase in the average annual discharge is recorded (Fig. $3 \mathrm{~A}$ );

${ }^{2}$ Until 1991 the observations were conducted at the gauging station in Sobolewo.
$\Rightarrow$ downstream of its outflow from Lake Wigry from $1.62 \mathrm{~m}^{3} \mathrm{~s}^{-1}$ (1969) to $6.89 \mathrm{~m}^{3} \mathrm{~s}^{-1}$ (1958), with an average annual discharge of $3.82 \mathrm{~m}^{3} \mathrm{~s}^{-1}$; at this gauging station a year-to-year decrease in the average annual discharge is recorded (Fig. 3 B).

The observed trends of the Czarna Hańcza's discharge, both upstream and downstream of Lake Wigry, indicate that the water supply of this river into the lake is increasing, while the outflow is decreasing (Fig. 4).

Comparing the difference in the size of the annual inflow of the Czarna Hańcza to Lake Wigry and its outflow from the lake with the average annual water level in Lake Wigry (Fig. 5), it can be noted that this correlation changed after 1990. The question is whether this results in changes in the structure of the water circulation in the lake.

The balance calculations (Bajkiewicz-Grabowska 2002, 2009) show there is a significant correlation between the volume of the stream of potamic exchange and that of the stream of underground water exchange in Lake Wigry (Fig. 6). It can therefore be assumed that the changes observed in Lake Wigry in the volume of the potamic water exchange, especially the river outflow from the lake, may be due to a change in the phase of the underground water circulation. 


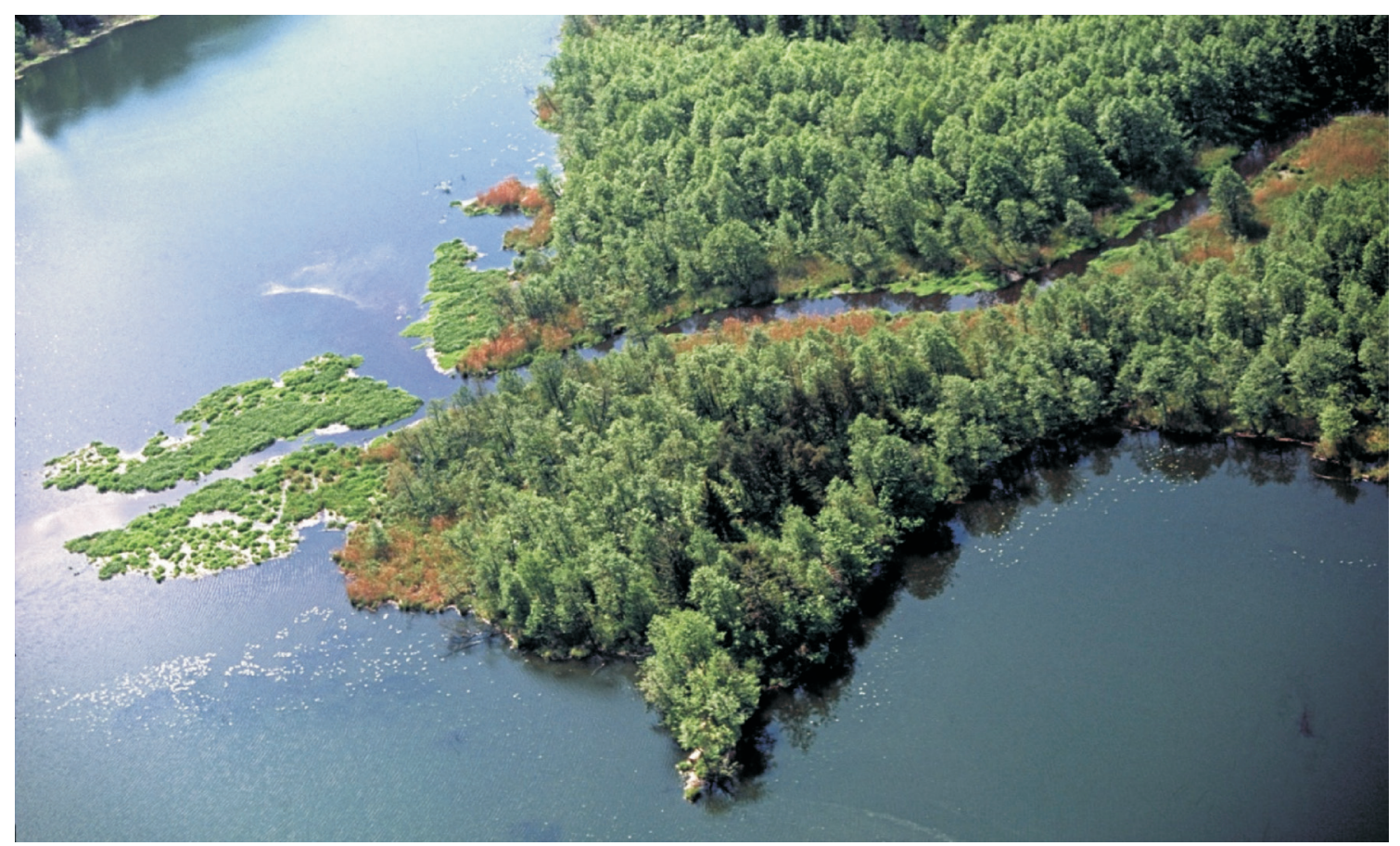

Fig. 2. Mouth of the Czarna Hańcza River (source: Osewski 2012)

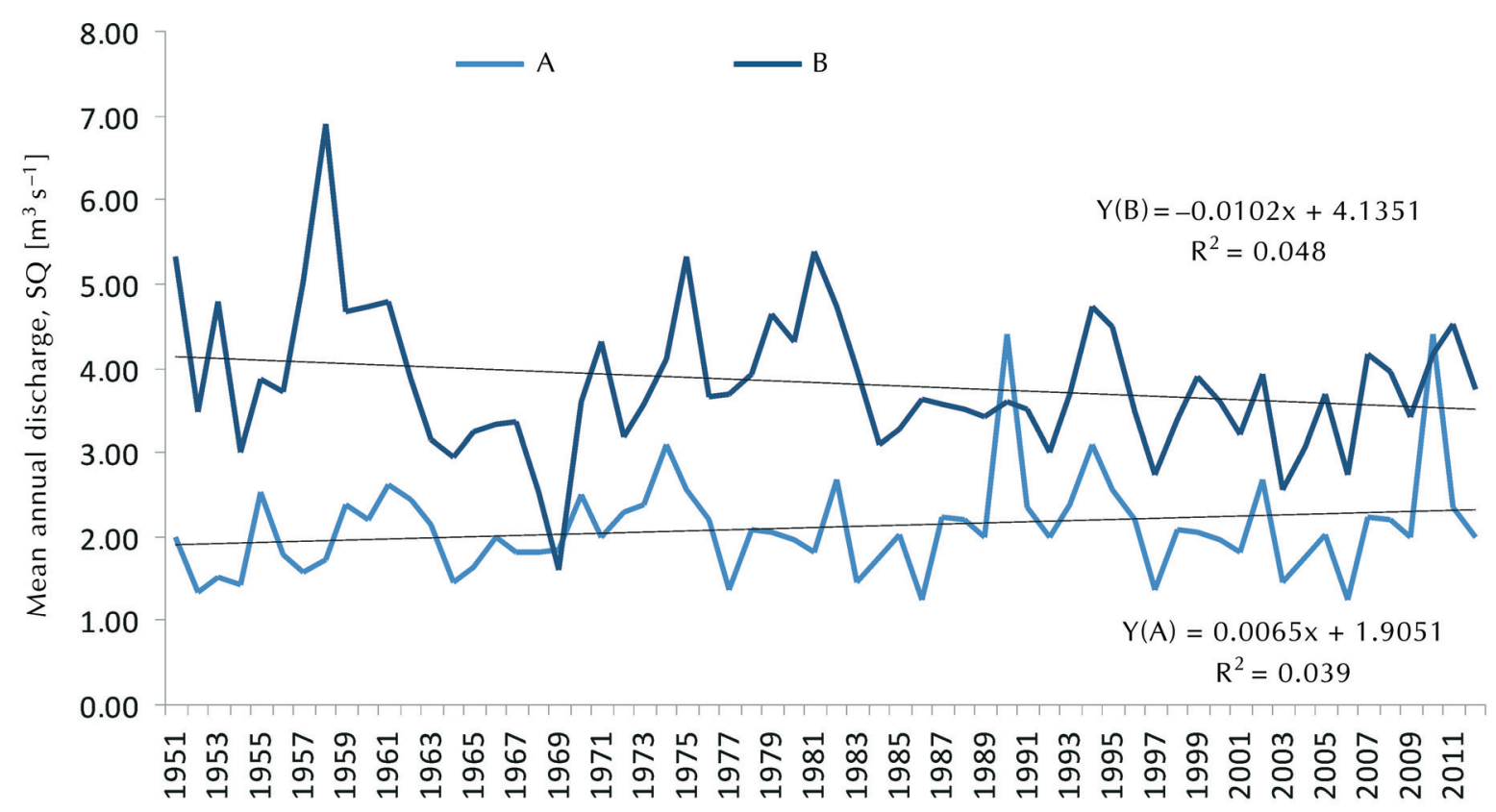

Fig. 3. Changes in the mean annual discharge of the Czarna Hańcza upstream (A) and downstream (B) of Lake Wigry in the years 19512010 (IMGW data) 


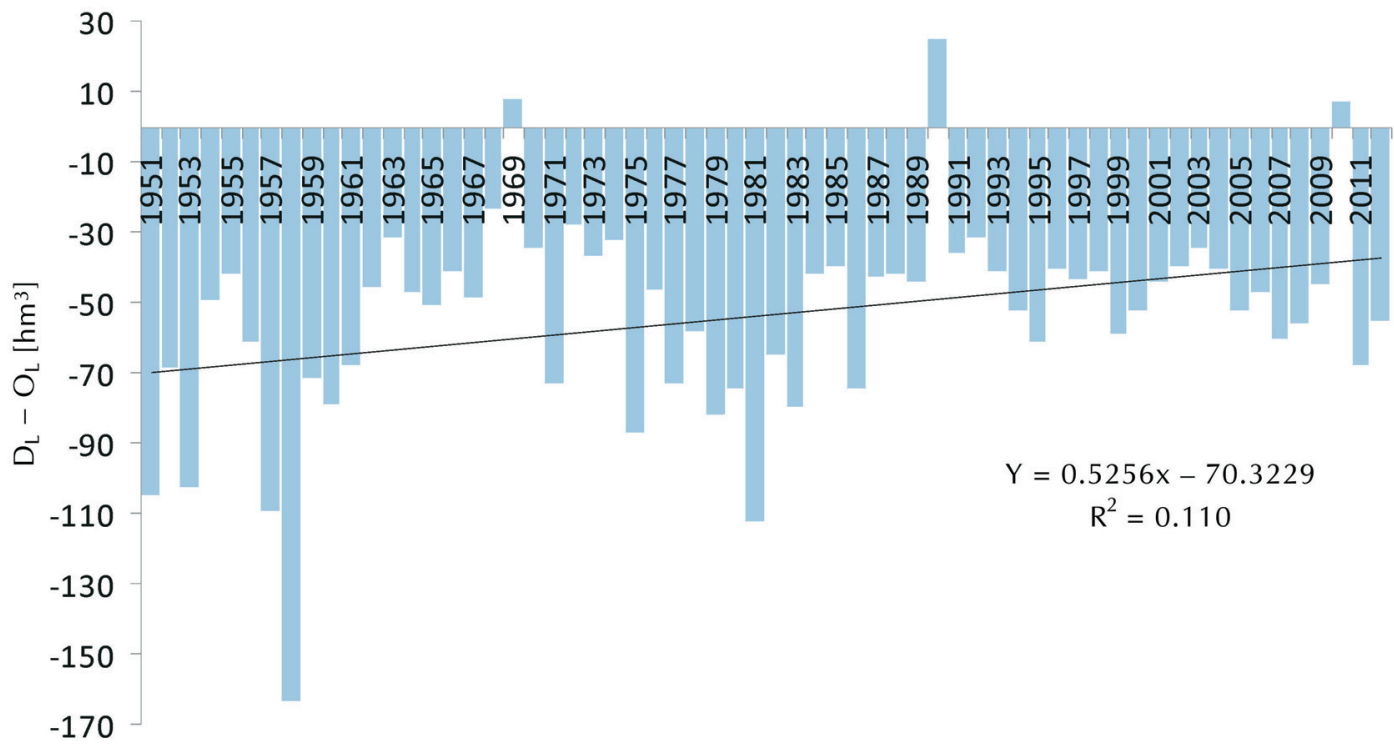

Fig. 4. Annual magnitude of the difference between the inflow of the Czarna Hańcza to Lake Wigry and the outflow from the lake in the period from 1951 to 2012 as well as the trend of the change

Fig. 5. Correlation between the mean annual water stages in Lake Wigry (SW) and the differences in the annual runoff of the Czarna Hańcza River upstream of its confluence with Lake Wigry and downstream of its outflow from the lake in the years 1951-2010

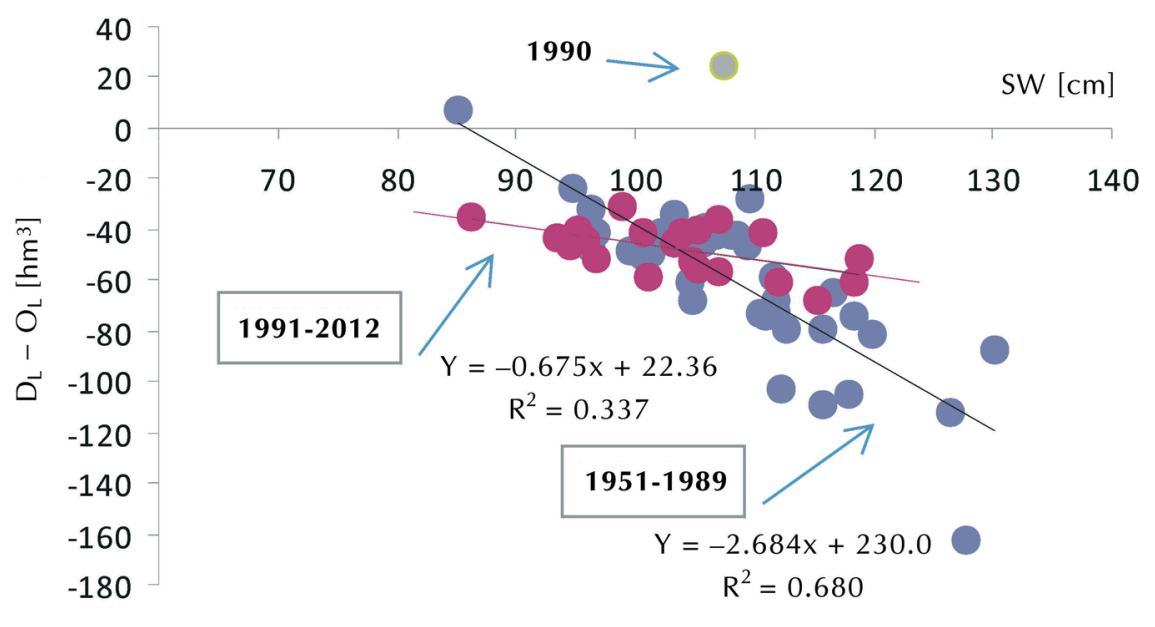

Fig. 6. Correlation between the stream of potamic exchange (inflow and outflow via the river) and the stream of the underground exchange (resultant of the underground supply) in Lake Wigry

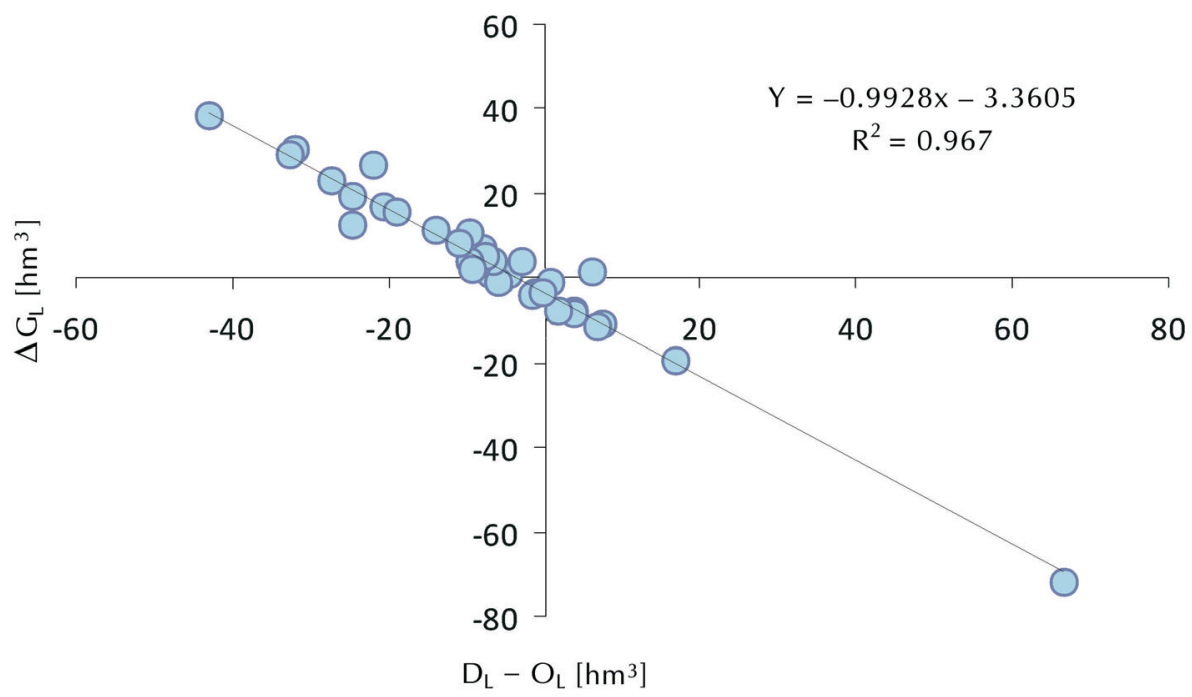


Structure of the water circulation in Lake Wigry

The structure of the lake water circulation is determined by the streams of its water exchange. These streams are as follows:

$\Rightarrow$ atmospheric water exchange, i.e. the difference between the amount of water brought into the lake by precipitation $\left(\mathrm{P}_{\mathrm{L}}\right)$ and the amount of water that evaporates from the surface of the lake to the atmosphere $\left(\mathrm{E}_{\mathrm{L}}\right)$,

$\Rightarrow$ potamic (horizontal) water exchange, i.e. the difference between the amount of water flowing into the lake over the surface (inflow via watercourses and the supply from the direct catchment of the lake, which is $\left.\mathrm{D}_{\mathrm{L}}\right)$ and the outflow from the lake $\left(\mathrm{O}_{\mathrm{L}}\right)$,

$\Rightarrow$ underground water exchange, i.e. the difference between the amount of water flowing into the lake via the underground inflow (underground supply) and flowing out of the lake to the groundwater (underground drainage), which is called the resultant underground supply $\left(\Delta \mathrm{G}_{\mathrm{L}}\right)$; when the sign of this component is positive the underground phase of the water circulation in the lake is dominated by the underground supply, but when the sign is negative the underground outflow from the lake dominates.

The sum of these streams shapes the retention state of the lake $\left(\Delta \mathrm{R}_{\mathrm{L}}\right)$. If the water circulation in the lake in a given period is balanced then the retention of the lake is zero.

The volume of the streams of water exchange in a lake is determined from the equation of the water balance of the lake (incl. Bajkiewicz-Grabowska 2002, 2009).

The balance calculations carried out on the basis of the observations from the years 1971-1995 and 2001-2008 indicate that the annual volume of water involved in the circulation in the lake ranges from 4.417 (1976) to $73.113 \mathrm{hm}^{3}$ (1990) (Fig. 7), which is an average of $16.745 \mathrm{hm}^{3}$.

The atmospheric exchange stream (the difference between precipitation and evaporation) in the period from 1971 to 2008 shows no change; there are, however, changes in the volume of the streams of potamic exchange (the difference between the river inflow and outflow) (Fig. 4) and the streams of underground exchange (underground supply resultant) (Fig. 8). This demonstrates the growing role of the inflow to the lake in shaping the stream of the potamic water exchange in the lake and the changes in the underground phase of the water circulation in the lake, which means either a reduction in the underground supply into the lake or an increase in the outflow of the lake water to the aquifers.

It seems that the turning point in which the change in the structure of the water circulation in Lake Wigry took place was the year 1990. This is indicated by the average lake water balances for the periods 1971-1990 and 2001-2008. The lake water balance from the years 1971-1990 shows that $8.897 \mathrm{hm}^{3}$ of water participated in the water circulation in an average year of this period. Out of it $43 \%$ came from the atmospheric exchange (surplus of precipitation over

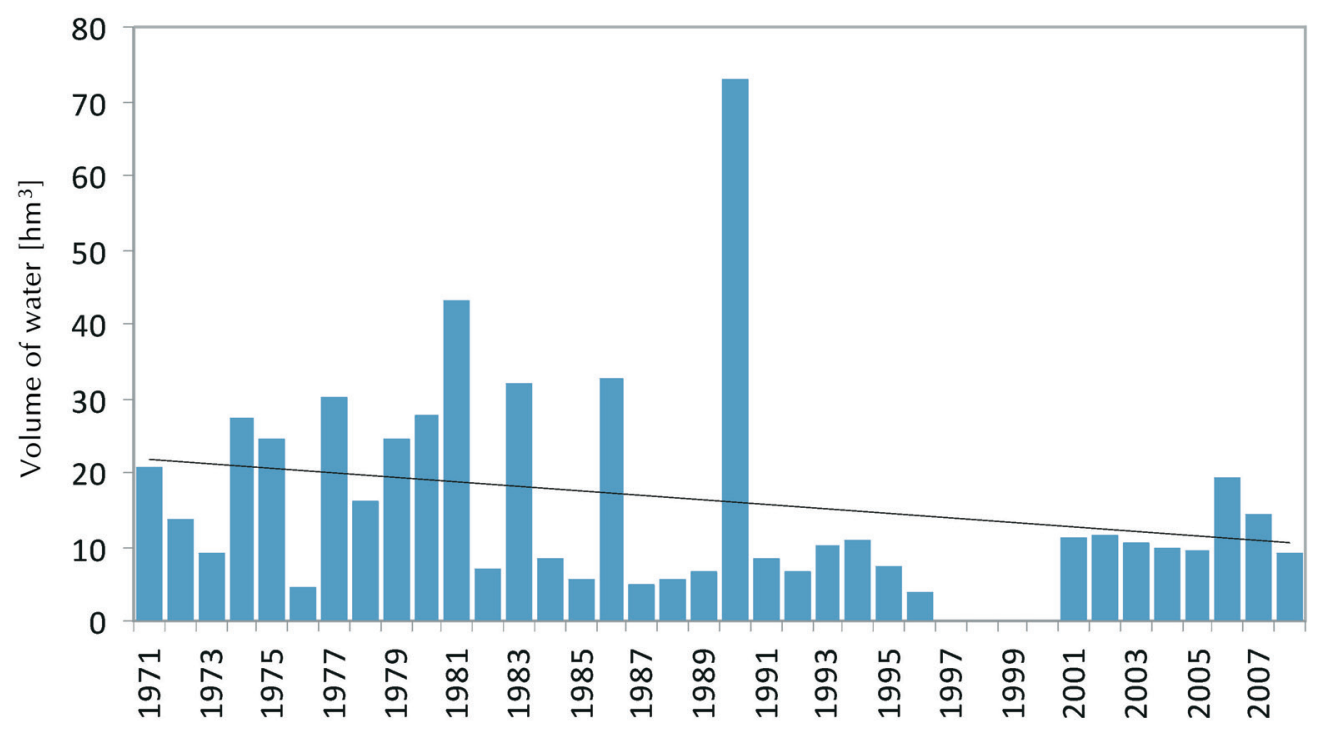

Fig. 7. Annual variability of the volume of water exchange in Lake Wigry in the years 1971-2008 and the trend of the change 


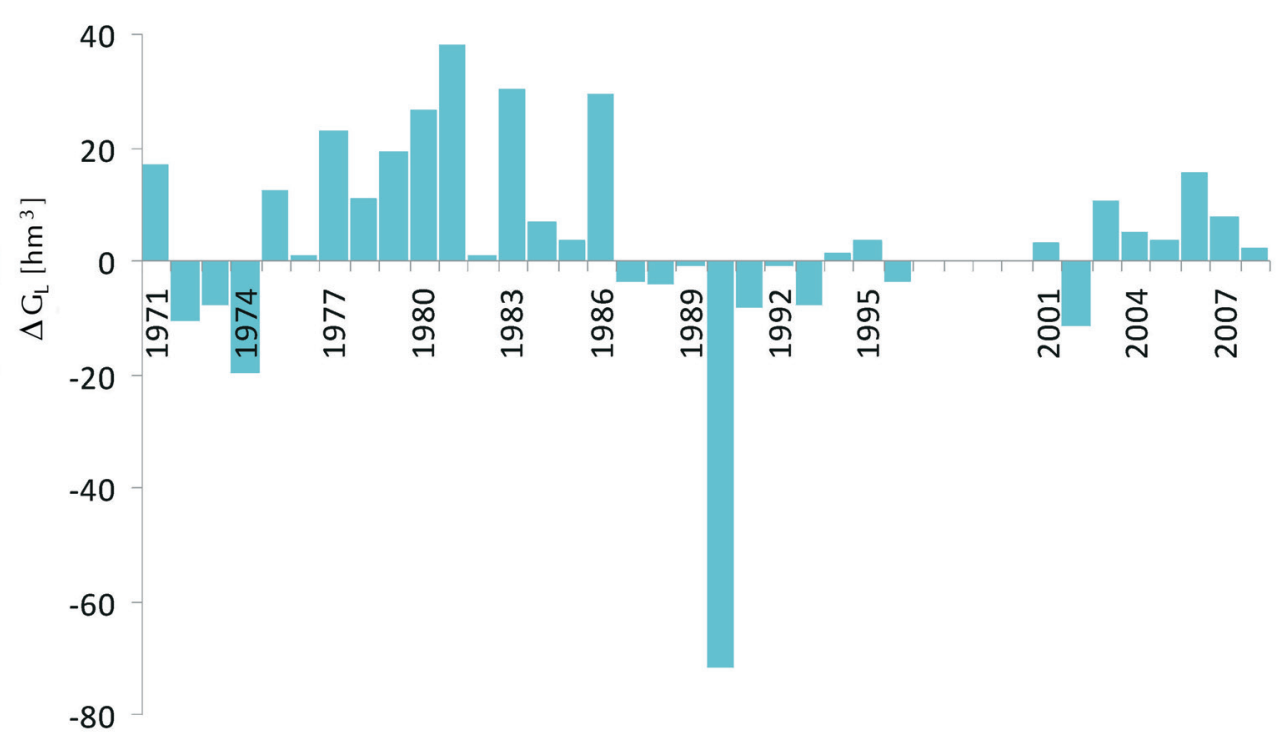

Fig. 8. Annual volume of water involved in the underground exchange in Lake Wigry with the trend of the change

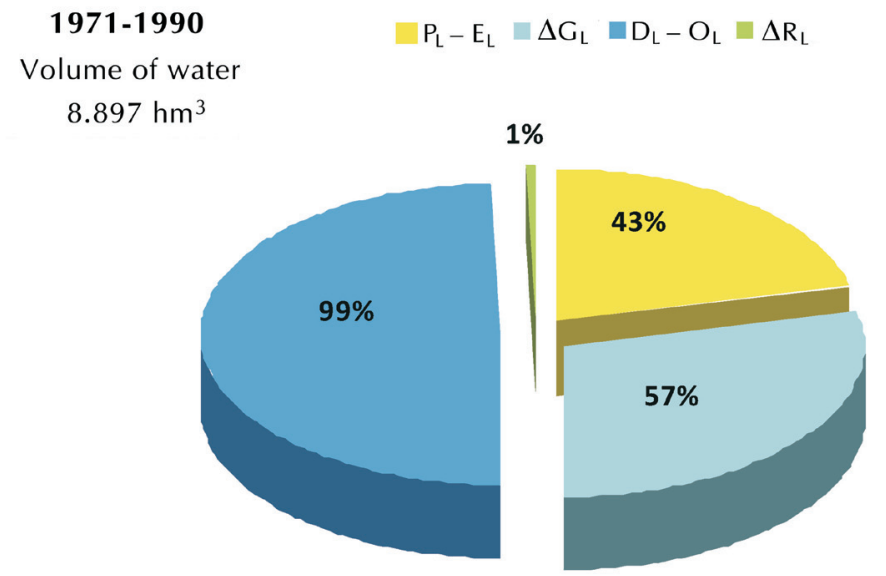

Fig. 9. Water balance for Lake Wigry in an average year from the period 1971-1990

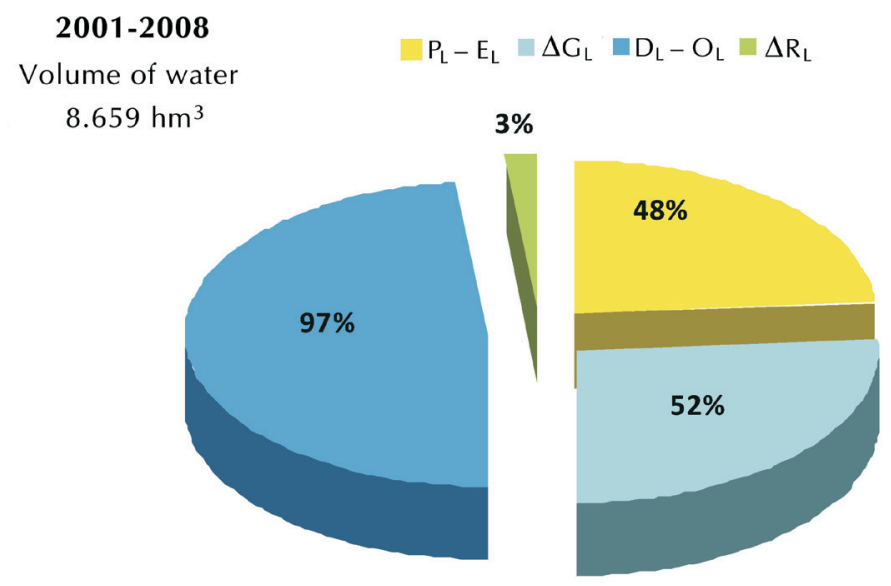

Fig. 10. Water balance for Lake Wigry in an average year from the period 2001-2008 
evaporation) and 57\% from the underground drainage (in the underground phase of circulation a surplus of the underground supply to the lake of $5.067 \mathrm{hm}^{3}$ ). Almost all the water obtained in this way (99\%) was drained from the lake via the Czarna Hańcza (8.820 $\mathrm{hm}^{3}$ ) and only $1 \%$ remained in the form of retention of the lake (Fig. 9).

In an average year of the period from 2001 to $2008,8.659 \mathrm{hm}^{3}$ of water participated in the lake circulation. In an average year of this period the water supply to the lake also came from the atmospheric exchange and underground drainage. The surplus of precipitation from the atmospheric exchange was $4.158 \mathrm{hm}^{3}$ of water $(48 \%$ of the total amount of water brought to the lake that year), and of the underground exchange, $4.500 \mathrm{hm}^{3}$ (52\%) (Fig. 10). 97\% of the water which in the balance year was supplied to the lake, i.e. $8.369 \mathrm{hm}^{3}$, was drained via the Czarna Hańcza, while $3 \%$ was added to the lake retention resources. In an average year between 2001 and 2008 the volumes of the potamic and underground streams of water exchange in the lake were smaller than in an average year between 1971 and 2000 .

\section{Conclusion}

The stability of water circulation in the lake guarantees the stability of its water resources. Any change in the streams of the water exchange in the lake should be monitored. As demonstrated, the changes in the volume of the potamic stream of water exchange, due to increased river inflow into the lake and the reduction in the outflow, may lead to changes in the volume of the streams of water exchange in the underground phase of its circulation.
Despite the changes in the volume and direction of the underground stream of water exchange (from the surplus of the underground supply to the surplus of the underground drainage), as observed in the late 1980s, Lake Wigry is still a reservoir draining the aquifers. The resultant of the underground supply of the lake, however, is lower than before 1990. This may be due to the reduction in the groundwater drainage or increase in the lake water supply to the aquifers.

\section{References}

Bajkiewicz-Grabowska E., 1999, Bilans wodny jeziora Wigry w latach 1981-1995 (Water balance for Lake Wigry for 1981-1995), [in:] Zdanowski B., Kamiński M., Martyniak A. (eds.), Funkcjonowanie i ochrona ekosystemów wodnych na obszarach chronionych. (Functioning and protection of water ecosystems in protected areas), Wyd. IRS, Olsztyn: 113-129 (in Polish).

Bajkiewicz-Grabowska E., 2002, Obieg materii w systemach rzeczno-jeziornych (Circulation of matter in the riverlake systems), WGiSR UW, Warszawa, p. 274 (in Polish, English summary).

Bajkiewicz-Grabowska E., 2009, Water circulation in a lake at extreme water levels: Lake Wigry case study, Limnol. Rev. 9(2-3): 63-72.

Dąbrowski M., 2002, Changes in the water level of lakes in northeastern Poland, Limnol. Rev. 2: 85-92.

Dąbrowski M., Węglarczyk S., 2005, Cyclical nature of fluctuations in the levels of lakes of Northern Poland, Limnol. Rev. 5: 61-67.

[IMGW] Instytut Meteorologii i Gospodarki Wodnej (Institute of meteorology and Water Management), 2005, Atlas podziału hydrograficznego Polski (Hydrographic Atlas of Poland), IMGW, Warszawa (in Polish).

Osewski M., 2012, Jeziora i rzeki WPN (Lakes and rivers of the Wigry National Park), WPN, Krzywe, pp. 9 (in Polish). Retrieved from: http://www.wigry.win.pl/wody/ wody.htm 